\title{
PEMANFAATAN LIMBAH TAHU SKALA RUMAH TANGGA MENJADI BIOGAS SEBAGAI UPAYA TEKNOLOGI BERSIH DI LABORATORIUM PUSAT TEKNOLOGI LINGKUNGAN - BPPT
}

\author{
Hanifah Nisrina* dan Pertiwi Andarani \\ Departemen Teknik Lingkungan, Fakultas Teknik, Universitas Diponegoro, Jl. Prof. Soedarto, \\ $\mathrm{SH}$, Kampus Undip Tembalang, Semarang, Indonesia 50275 \\ e-mail : hanifahnisrinar98@gmail.com
}

\begin{abstract}
Abstrak
Limbah cair yang dihasilkan industri tahu sangat merugikan lingkungan jika tidak dilakukan pengolahan terlebih dahulu. Namun, limbah cair tahu dapat diolah secara anaerob sehingga menghasilkan biogas. Maka dari itu, penelitian ini bertujuan untuk mengetahui besarnya potensi biogas yang dapat dihasilkan dari limbah cair tahu sebagai upaya dalam teknologi bersih serta mengetahui kelayakannya dari aspek ekonomi dan lingkungan. Penelitian dilakukan pada industri tahu skala rumah tangga yang berlokasi di Desa Puspiptek, Tangerang Selatan dengan metode digesti anaerobik. Hasil penelitian menunjukkan bahwa selama waktu tinggal 14 hari, limbah tahu menghasilkan biogas sebesar 1.525 liter dengan penurunan kandungan COD sebesar 8,1\% dari 748,75 mg/L menjadi 688,125 mg/L, Total Solid sebesar 56,9\% dari 16,36 $\mathrm{g} / \mathrm{L}$ menjadi 7,049 $\mathrm{g} / \mathrm{L}$, dan Volatile Solid sebesar 66,3\% dari 14,85 g/L menjadi 5,001 g/L. Hasil analisis simulasi kelayakan biogas berdasarkan aspek ekonomi berupa Harga Pokok Penjualan (HPP) Rp7.342 per kg, BEP 109.500 kg/tahun, dan PBP 0,48 dengan pengolahan limbah tahu sebesar 5676 liter per hari, menghasilkan biogas sebanyak $5,174 \mathrm{~m}^{3}$ per hari. Banyak sekali manfaat yang didapat dari pemanfaatan limbah menjadi biogas, baik dari aspek ekonomi, lingkungan, maupun sosial.
\end{abstract}

Kata kunci: biogas; limbah tahu; digesti anaerobik; teknologi bersih; kelayakan biogas

\begin{abstract}
The waste water of tofu industry is very harmful if disposed to the environment without any treatment process. In the other hand, tofu waste water can be treated in anaerobic condition to produce biogas. Therefore, this study aims to determine the potential of biogas that can be generated from tofu waste as an effort in cleaner technology and determine the feasibility of economic and environmental aspects. The research was conducted in a household-scale tofu industry located in Puspiptek Village, South Tangerang with anaerobic digestion method. The result showed that during 14 days of retention time, the tofu waste generated 1,525 liters of biogas with a decrease of COD content by $8.1 \%$ from $748.75 \mathrm{mg} / \mathrm{L}$ to $688.125 \mathrm{mg} / \mathrm{L}$, total solid by $56.9 \%$ from $16.36 \mathrm{~g} / \mathrm{L}$ to $7.049 \mathrm{~g} / \mathrm{L}$, and volatile solid by $66.3 \%$ from $14.85 \mathrm{~g} / \mathrm{L}$ to $5.001 \mathrm{~g} / \mathrm{L}$. The results of biogas feasibility analysis based on economic aspect are principle price of Rp7,342 per kg, Break Even Point (BEP) of 109,500 kg per year, and Pay Back Period (PBP) of 0.48 with 5,676 liters of tofu waste water processed per day. It can produce $5.174 \mathrm{~m}^{3}$ biogas per day. Lots of benefits derived from this waste-to-energy method into biogas, including economy, environmental, and social aspects.
\end{abstract}

Keywords: biogas, tofu waste, anaerobic digestion, cleaner technology, biogas feasibility

\section{Pendahuluan}

Pada era teknologi saat ini, peningkatan pada permintaan bahan bakar fosil telah meningkat secara pesat yang mengakibatkan pemanasan global dan efek rumah kaca (Sulistyono, 2016). Oleh karena itu, dibutuhkan energi terbaharukan sebagai alternatif bahan bakar yang ramah lingkungan. Salah satu energi terbaharukan adalah biogas, di mana biogas adalah gas yang dihasilkan oleh aktivitas anaerobik atau fermentasi dari bahan-bahan organik oleh mikroorganisme anaerob. Untuk memperoleh 
energi biogas, dapat menggunakan metode digesti anaerobik. Metode ini menggunakan beragam jenis mikroba yang dapat mengubah biomassa dan limbah menjadi biogas dengan cara mendegradasi material organik tanpa melibatkan oksigen dan bantuan bakteri (Olatunde, Oranusi, \& Enontiemonria, 2017).

Sumber bahan yang dapat digunakan pada biogas sangat beragam, contohnya adalah limbah tahu. Limbah industri tahu skala rumah tangga adalah limbah yang dihasilkan dalam proses pembuatan tahu maupun pada saat pencucian kedelai. Komposisi limbah cair tahu sebagian besar terdiri dari air $(99,9 \%)$ dan sisanya terdiri dari partikel-partikel padat terlarut (dissolved solid) dan tidak terlarut (suspended solid) sebesar $0,1 \%$. Partikel-partikel padat dari zat organik ( $\pm 70 \%$ ) dan zat anorganik ( $\pm 30 \%)$. Zat-zat organik terdiri dari protein ( \pm 65\%), karbohidrat ( $\pm 25 \%)$, lemak ( \pm 25\%) (Triwikantoro, 2012). Selain kandungan organik, limbah tahu juga mengandung kandungan BOD, COD, TSS yang cukup tinggi. Apabila dilihat dari baku mutu air limbah bagi usaha dan/atau kegiatan pengolahan kedelai menurut Peraturan Menteri Lingkungan Hidup Republik Indonesia Nomor 5 Tahun 2014 tentang Baku Mutu Air Limbah, kadar maksimum yang diperbolehkan untuk $\mathrm{BOD}_{5}, \mathrm{COD}$ dan TSS berturut-turut adalah $150 \mathrm{mg} / \mathrm{L}, 300 \mathrm{mg} / \mathrm{L}$, dan $200 \mathrm{mg} / \mathrm{L}$ dengan $\mathrm{pH}$ 6-9. Sebagian besar limbah cair tahu langsung dibuang ke lingkungan tanpa pengolahan terlebih dahulu. Hal tersebut sangat disayangkan, sebanyak lebih dari 50\% air limbah tahu mempunyai kandungan Metana $\left(\mathrm{CH}_{4}\right)$, sehingga sangat memungkinkan untuk menjadi bahan sumber energi biogas, seperti memasak, pemananasan, atau dikonversi menjadi listrik (Maragkaki, Fountoulakis, Kyriakou, Lasaridi, \& Manios, 2018).

Berdasarkan kondisi ini, penelitian yang dilakukan adalah pemanfaatan limbah tahu dengan bantuan starter mikroorganisme dari kotoran sapi guna mengetahui potensi kelayakan energi biogas tersebut sebagai upaya teknologi bersih yang dilaksanakan pada Laboratorium Pusat Teknologi PTL BPPT. Dengan melakukan penelitian ini, diharapkan dapat mengetahui kelayakan potensi energi biogas dari limbah tahu skala rumah tangga tersebut.

\section{Metodologi Penelitian}

Penelitian dilakukan pada industri tahu skala rumah tangga di Desa Puspiptek, Tangerang Selatan. Bahan yang digunakan dalam penelitian ini adalah limbah cair tahu dan kotoran sapi sebagai starter. Alat yang digunakan yaitu digester anaerobik tipe batch dengan kapasitas volume 20 liter, gelas pengukur volume biogas $650 \mathrm{ml}$, magnet pump CXB - 10, dan beberapa alat penunjang lainnya. Berikut pada Gambar 1 adalah proses produksi tahu.

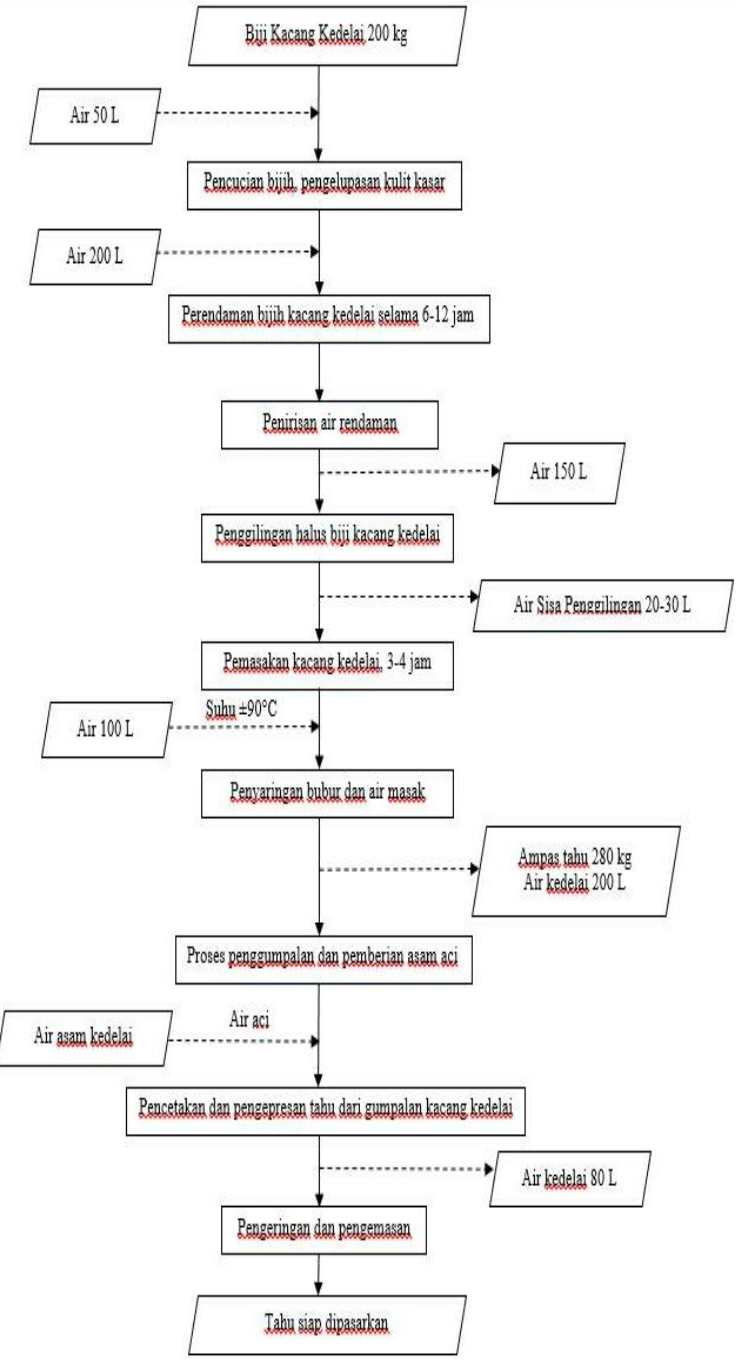

Gambar 1. Proses Produksi Tahu

Reaktor yang digunakan adalah digester anaerobik skala batch dengan kapasitas 20 liter.

Langkah pengujian:

a. Identifikasi awal limbah tahu dan kotoran sapi dengan parameter COD, total dan volatile solid, $\mathrm{pH}$, dan suhu.

b. Seeding inokulum dengan kotoran sapi dan air dicampurkan hingga homogen dengan perbandingan 1: 6 yang dimasukkan pada drum dengan penyaringan.

c. Aklimatisasi inokulum dengan penambahan 1 liter limbah tahu yang telah disaring, kemudian dimasukkan pada seeding drum. 
d. Dilakukan pengadukan secara berkala serta uji pH dan perubahan tekanan pada balon karet yang dipasang pada lubang kontrol diamati.

e. Empat belas liter inokulum yang telah teraktivasi dimasukkan ke dalam reaktor dengan penambahan 2 liter limbah tahu

f. Ruang kosong dalam reaktor disisakan sebesar $20 \%$ sebagai tempat fermentasi gas metan.

g. Uji suhu dan $\mathrm{pH}$ setiap harinya dan pengukuran gas pada measurement glass diamati.

h. Karena gas yang terbentuk tercampur dengan udara pada awal pengujian, maka gas tersebut harus dibuang melalui kran pembuangan.

i. Setelah reaktor dalam kondisi anaerob, penambahan volume gas dicatat.

j. Setiap hari, limbah tahu sebanyak 1 liter ditambahkan dan diperhatikan kondisi mikroorganisme dalam reaktor dengan uji $\mathrm{pH}$, jika berada pada rentan asam, inokulum ditambahkan pada reaktor.

k. Pada akhir waktu pengujian, identifikasi lumpur efluen dengan parameter COD, total dan volatile solid, $\mathrm{pH}$, dan suhu.

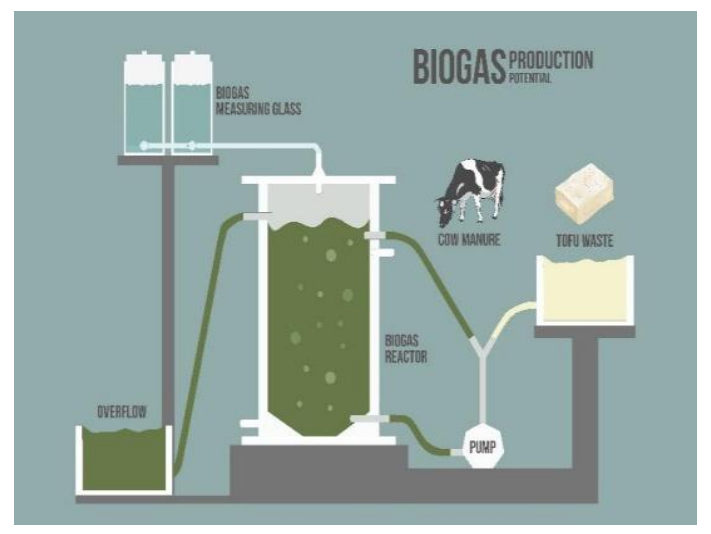

Gambar 2. Skema Set-up Alat

\section{Hasil dan Pembahasan}

Mengidentifikasi limbah tahu dan inokulum, proses seeding dan aklimatisasi, identifikasi kebocoran gas, analisis kuantitatif dan kualitatif harian, identifikasi lumpur efluen, serta kelayakan limbah tahu sebagai biogas.

\section{Identifikasi Limbah Tahu dan Inokulum}

Identifikasi limbah tahu dan inokulum dilakukan untuk menentukan mengetahui karakteristik awal limbah dan inokulum yang digunakan sebelum dilakukan uji biogas, didapatkan data yang tercantum pada Tabel 1.
Tabel 1. Idenfitikasi Limbah Tahu dan Inokulum

\begin{tabular}{|c|c|c|c|c|c|}
\hline \multirow[b]{2}{*}{ Uji } & \multicolumn{2}{|c|}{ Solid (g/l) } & \multirow{2}{*}{$\begin{array}{l}\text { COD } \\
(\mathrm{mg} / \mathrm{l})\end{array}$} & \multirow{2}{*}{$\begin{array}{c}\text { Suh } \\
\underset{\mathbf{u}}{\left({ }^{\circ} \mathrm{C}\right)}\end{array}$} & \multirow[b]{2}{*}{$\mathrm{pH}$} \\
\hline & Total & $\begin{array}{c}\text { Volatil } \\
e\end{array}$ & & & \\
\hline $\begin{array}{l}\text { Limbah } \\
\text { Tahu }\end{array}$ & 16,63 & 14,85 & $\begin{array}{c}748,7 \\
5\end{array}$ & 46 & $\begin{array}{c}4,3 \\
0\end{array}$ \\
\hline Inokulum & 8,3 & 6,5 & $\begin{array}{c}712,7 \\
5\end{array}$ & 28 & $\begin{array}{c}6,8 \\
9\end{array}$ \\
\hline
\end{tabular}

Dari Tabel 1, didapatkan nilai total solid untuk limbah tahu sebesar 16,63 g/l, sedangkan volatile solid sebesar 14,85 g/l. Total Solid menunjukkan kandungan padatan organik dan anorganik dalam air, yang mana volatile solid merepresentasikan kandungan padatan organik. Hal ini menunjukkan bahwa limbah tahu mengandung padatan organik sebesar $89,3 \%$. Kemudian, perbandingan TS dan VS pada inokulum juga tidak berbeda jauh dengan perbandingan TS dan VS pada limbah tahu, yakni untuk total solid sebesar $8,3 \mathrm{~g} / \mathrm{l}$ dan untuk volatile solid sebesar $6,5 \mathrm{~g} / \mathrm{l}$. Hal ini menunjukkan bahwa inokulum mengandung padatan organik sebesar $78,32 \%$. Nilai COD dari limbah tahu maupun inokulum sangat tinggi. Dibandingkan dengan baku mutu industri tahu yang tercantum pada Peraturan Mentri Lingkungan Hidup Republik Indonesia No. 5 Tahun 2014 Tentang Baku Mutu Air Limbah bagi usaha pengolahan kedelai, khususnya pembuatan tahu nilai COD yang diizinkan yaitu sebesar $300 \mathrm{mg} / \mathrm{L}$ dan untuk peternakan sapi COD yang diizinkan sebesar 200 mg/L. Namun, dari hasil pengujian COD, didapatkan nilai COD limbah tahu dan inokulum yang melampaui baku mutu, yaitu berturut - turut sebesar 748,75 dan $712,75 \mathrm{mg} / \mathrm{L}$. Nilai $\mathrm{pH}$ ampas tahu berkisar 4,03 dengan suhu $46^{\circ} \mathrm{C}$ yang berpotensi mengalami pengasaman, sedangkan untuk inokulum dengan $\mathrm{pH}$ 6,89 dengan suhu $28{ }^{\circ} \mathrm{C}$ masih tergolong $\mathrm{pH}$ netral.

\section{Proses Seeding dan Aklimatisasi}

Identifikasi proses seeding dilakukan dengan mengukur tekanan gas yang diukur dengan menggunakan media balon karet dan juga pengujian nilai $\mathrm{pH}$. Data yang didapatkan dapat dilihat pada Tabel 2.

Tabel 2. Hasil Uji pH Seeding

\begin{tabular}{cccc}
\hline & \multicolumn{3}{c}{ Nilai pH } \\
\cline { 2 - 4 } & $\begin{array}{c}\text { Rabu } \\
(17 / 1 / 18)\end{array}$ & $\begin{array}{c}\text { Kamis } \\
(18 / 1 / 18)\end{array}$ & $\begin{array}{c}\text { Jumat } \\
(19 / 1 / 18)\end{array}$ \\
\hline Seeding & 6.58 & 6.62 & 6.56 \\
\hline
\end{tabular}

Pembiakan bakteri yang dimaksud adalah adanya kehidupan bakteri dalam suatu zat. Bakteri yang berkembangbiak akan melakukan metabolisme, yaitu proses yang membutuhkan nutrisi untuk meregenerasi sel tubuhnya dan menghasilkan energi ataupun 
produk lainnya (Indriyati, 2003). Dari Tabel 2, dapat dilihat bahwa $\mathrm{pH}$ seeding konstan pada rentan netral, yaitu pada hari Rabu (17/1/18), Kamis (18/1/18), dan Jumat (19/1/18) berturut - turut adalah 6.58, 6.62, dan 6.56.

Sedangkan proses aklimatisasi adalah upaya untuk mengetahui tingkat kemampuan bakteri bertahan hidup dan beradaptasi pada suatu kondisi (Indriyati, 2003). Proses aklimatisasi dilakukan selama 4 (empat) hari, yaitu hari Jumat, tanggal 19 Januari 2018 $(19 / 1 / 18)$ hingga hari Senin, tanggal 22 Januari 2018. Proses aklimatisasi dikatakan berhasil ketika nilai $\mathrm{pH}$ netral dan stabil. Pada akhir proses aklimatisasi nilai $\mathrm{pH}$ yaitu sebesar 6.80 .

\section{Identifikasi Kebocoran Gas}

Kebocoran gas merupakan hal yang sangat tidak menguntungkan dalam produksi biogas. Oleh karena itu, diperlukan suatu upaya identifikasi kebocoran gas. Beberapa titik kebocoran terletak pada reaktor digesti anaerobik, yaitu pada overflow yang disambungkan dengan selang elastis dan dicelupkan pada ember, kemudian pada dinding penutup reaktor. Selain itu, pada gelas pengukur volume biogas terdapat titik kebocoran pada lubang inflow serta penutup gelas.

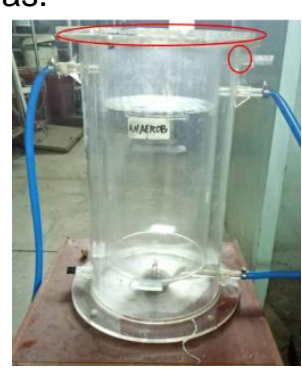

(a)

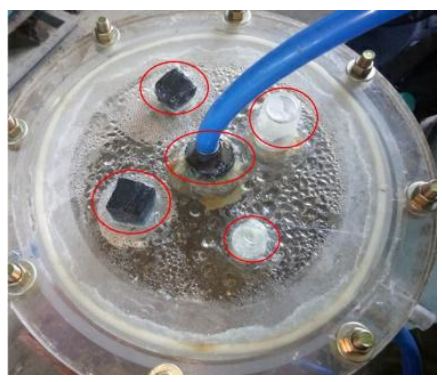

(c)

Gambar 3. Identifikasi Potensi Kebocoran Keterangan:

(a) Titik - titik kebocoran gas pada reaktor

(b) Titik - titik kebocoran gas pada selang (c) Titik - titik kebocoran gas pada dinding penutup reaktor

Dari titik - titik kebocoran tersebut, teradapat beberapa solusi yang dapat dilakukan, yaitu pada overflow dipasangkan valve kompresor dan dicelupkan pada ember berisi air. Pada kebocoran di lubang penutup reaktor, dilakukan pelapisan lubang penutup reaktor dengan menggunakan lem silikon. Kemudian kebocoran pada selang gelas pengukur volume biogas, dilakukan penggantian selang baru dan dilapisi dengan lem silikon dan sealt tape.

Menurut (Clemens, Kohne, Weser-ems, \& Schreier, 2012), terdapat beberapa cara untuk mendeteksi adanya kebocoran pada reaktor biogas, yaitu dengan melakukan pengecekan tekanan, leakage spray, laser gas, dan kamera inframerah. Pendeteksi adanya kebocoran biogas dengan cara pengecekan tekanan diidentifikasikan dengan adanya penurunan tekanan gas secara signifikan. Cara kedua yaitu dengan leakage spray, semprotan ini berbentuk busa, ketika telah teridentifikasi adanya kebocoran biogas, maka busa tersebut akan berubah warna. Selanjutnya adalah laser gas, laser ini berbentuk seperti remote ac yang memiliki monitor untuk menginformasikan adanya kebocoran gas. Cara terakhir adalah dengan kamera inframerah, kamera ini menggunakan sinyal inframerah untuk mendeteksi adanya kebocoran.

\section{Analisis Kuantitatif dan Kualitatif Harian}

Setelah dilakukan pengamatan selama 14 hari, didapatkan data pertambahan jumlah gas harian serta perubahan warna dan kondisi kualitatif pada objek penelitian. Data jumlah pertambahan gas harian ditunjukkan pada Tabel 3.

Tabel 3. Jumlah Pertambahan Gas

\begin{tabular}{|c|c|c|c|}
\hline \multirow{2}{*}{ No } & \multirow{2}{*}{ Tanggal } & \multicolumn{2}{|c|}{ Volume Biogas (ml) } \\
\hline & & Harian & Akumulasi \\
\hline 1 & 23-Jan-18 & 0 & 0 \\
\hline 2 & 24-Jan-18 & 75 & 75 \\
\hline 3 & 25-Jan-18 & 130 & 205 \\
\hline 4 & 26-Jan-18 & 70 & 275 \\
\hline 5 & 27-Jan-18 & 30 & 305 \\
\hline 6 & 28-Jan-18 & 90 & 395 \\
\hline 7 & 29-Jan-18 & 0 & 395 \\
\hline 8 & 30-Jan-18 & 95 & 490 \\
\hline 9 & 31-Jan-18 & 80 & 570 \\
\hline 10 & 1-Feb-18 & 600 & 1170 \\
\hline 11 & 2-Feb-18 & 180 & 1350 \\
\hline
\end{tabular}




\begin{tabular}{|c|c|c|c|}
\hline \multirow{2}{*}{ No } & \multirow{2}{*}{ Tanggal } & \multicolumn{2}{|c|}{ Volume Biogas (ml) } \\
\hline & & Harian & Akumulasi \\
\hline 12 & 3-Feb-18 & 90 & 1440 \\
\hline 13 & 4-Feb-18 & 75 & 1515 \\
\hline 14 & 5-Feb-18 & 10 & 1525 \\
\hline
\end{tabular}

diketahui bahwa jumlah gas terproduksi terbanyak adalah sebesar $600 \mathrm{ml}$ pada hari ke-10 dan terdapat hari tanpa adanya gas terproduksi, yaitu pada hari ke-7.

\section{Grafik Pertambahan Volume Biogas}

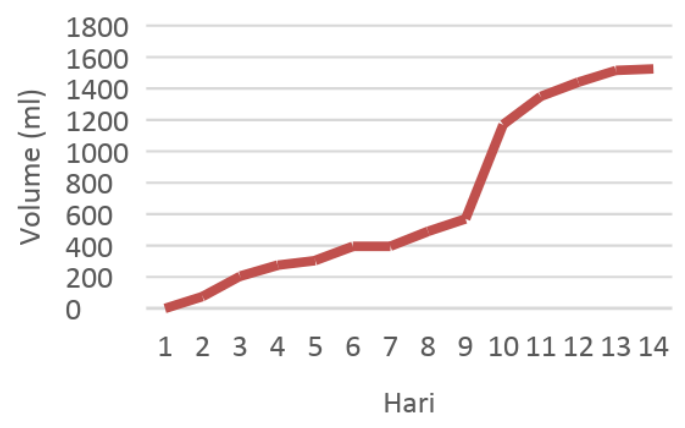

Gambar 4. Grafik Pertambahan Volume Biogas

Pada Gambar 4 menunjukkan grafik akumulasi pertambahan volume biogas. Dari grafik tersebut, dapat dikatakan bahwa selama 14 hari, volume biogas yang terproduksi cenderung mengalami peningkatan. Hari pertama dan kedua merupakan fase awal pembentukan gas dalam pembentukan biogas, yaitu hidrolisis dan asidogenesis. Pada tahap hidrolisis, bakteri memutuskan rantai panjang senyawa kompleks dari substrat, seperti selulosa, karbohidrat, protein, dan lemak (Deublien \& Angelika, 2008).

Pada hari ke-3 hingga ke-10, biogas yang terbentuk meningkat secara signifikan dan tidak mengeluarkan bau kotoran sapi yang menyengat seperti pada fase awal, maka dapat diindikasikan telah memasuki fase pembentukan biogas yang kedua, yaitu fase asetogenesis dan metanogenesis. Secara lebih mendalam, pada hari ke-3 hingga ke-6, proses yang terjadi dalam digester adalah fase asetogenesis, di mana substrat sederhana yang dihasilkan pada tahap asidogenesis digunakan untuk bakteri homoasetogenik pada tahap metanogenesis. Bakteri tersebut secara konstan mereduksi $\mathrm{H}_{2}$ dan $\mathrm{CO}_{2}$ dan mengubahnya menjadi asam asetik. Biogas terproduksi menunjukkan angka fluktuatif yang menandakan bahwa bakteri yang ada pada digester memiliki metabolisme yang cukup baik, namun masih terindikasinya kebocoran minor pada beberapa titik tertentu.
Kemudian, pada hari ke-7, digester tidak menghasilkan biogas sama sekali. Hal ini dikarenakan teridentifikasinya kebocoran yang cukup fatal pada penutup reaktor dan selang reaktor menuju gelas pengukur volume akibat tekanan gas yang cukup tinggi. Pada hari yang sama, titik kebocoran diperbaiki dan melakukan penambahan inokulum pada digester. Pada hari ke-8 hingga ke-10, bakteri - bakteri asetogenesis dan metanogenesis yang ada dalam digester sedang dalam kondisi optimal dalam melakukan degradasi. Hal ini terbukti dengan bau gas yang dihasilkan tidak berbau kotoran sapi, melainkan bau gas serta warna semakin pekat. Namun, pada hari ke-11 hingga ke-14, mulai terjadi penurunan produksi biogas. Pada fase ini, gas yang didapatkan pun masih tidak berbau, namun dari warna mulai menjadi hijau pucat. Sehingga diperkirakan bakteri dalam fase kedua telah kehabisan energi dan tidak mampu melakukan pereduksian senyawa.

Identifikasi Lumpur Efluen

Identifikasi lumpur efluen dilakukan sesuai dengan tahapan identifikasi limbah tahu dan inokulum. Identifikasi lumpur efluen ini bertujuan untuk mengidentifikasi proses yang sedang berlangsung selama pengujian uji potensi biogas. Berikut adalah data hasil identifikasi lumpur efluen pada Tabel 4.

Tabel 4. Identifikasi Lumpur Efluen

\begin{tabular}{lcccc}
\hline \multirow{3}{*}{ Sampel } & \multicolumn{4}{c}{ Sesudah Uji } \\
\cline { 2 - 5 } & $\begin{array}{c}\text { COD } \\
(\mathbf{m g} / \mathbf{L})\end{array}$ & $\begin{array}{c}\text { TS } \\
(\mathbf{g} / \mathbf{L})\end{array}$ & $\begin{array}{c}\text { VS } \\
(\mathbf{g} / \mathbf{L})\end{array}$ & $\mathbf{p H}$ \\
\hline Limbah & 688,125 & 7,049 & 5,001 & 5,82 \\
\hline
\end{tabular}

Dari data tersebut, dapat diketahui bahwa kandungan COD pada limbah tahu mengalami penurunan sebesar $8,1 \%$, yakni dari $748,75 \mathrm{mg} / \mathrm{L}$ menjadi $688,125 \mathrm{mg} / \mathrm{L}$. Penurunan nilai COD mengindikasikan bahwa bakteri - bakteri yang terdapat dalam digester telah bekerja dengan mendegradasi senyawa organik yang terdapat pada substrat dan mengubahnya menjadi biogas. Kecilnya penurunan nilai COD dapat disebabkan oleh waktu tinggal yang singkat, yaitu pada saat pengujian diberhentikan ketika substrat limbah belum mencapai titik loading rate, maka mikroorganisme yang bekerja belum mendegradasi senyawa organik secara maksimal akibat kurangnya waktu. Menurut penelitian produksi biogas yang dilakukan oleh (Hutagulung, 2017) dalam skripsinya, bahwa waktu optimum untuk memproduksi biogas dicapai dengan waktu tinggal 21 hari. Kandungan TS dan VS juga mengalami penurunan yang berturut - turut sebesar $56,9 \%$ dan $66,3 \%$, yakni untuk TS dari 16,36 
$\mathrm{g} / \mathrm{L}$ menjadi $7,049 \mathrm{~g} / \mathrm{L}$ dan untuk VS dari 14,85 g/L menjadi 5,001 $\mathrm{g} / \mathrm{L}$. Hal ini disebabkan oleh bahan organik yang terdapat dalam digester mengalami perombakan oleh bakteri, sehingga kandungan TS dan VS menjadi turun. Penurunan total solid (TS) dan volatile solid (VS) berindikasi dengan peningkatan produksi biogas atau kadar gas metan yang dihasilkan (Marsudi, 2012). Hal ini disebabkan karena volatile solid merupakan substrat bagi mikroorganisme non-metanogen yang bekerja pada tahap awal produksi biogas. Penurunan volatile solid menunjukkan bahwa terjadi proses degradasi senyawa organik oleh mikroorganisme. Kemudian untuk $\mathrm{pH}$, mengalami peningkatan dari 4,03 menjadi 5,82. $\mathrm{pH}$ merupakan salah satu faktor penting dalam melakukan uji potensial biogas. Selama waktu pengujian, nilai $\mathrm{pH}$ selalu menunjukkan angka yang fluktuatif, hal ini dapat disebabkan oleh belum siapnya bakteri - bakteri yang terdapat dalam digester dalam pengadaptasian terhadap substrat. Menurut Subekti (2011), dalam pelaksanaan proses seeding dan aklimatisasi, diharuskan rutin melakukan uji $\mathrm{pH}$, suhu, COD, TS, VS, dan pengukuran gas metan. Namun, peralatan laboratorium terbatas, sehingga uji yang dilakukan hanya $\mathrm{pH}$ dan suhu secara rutin. Hal lainnya yaitu pada saat waktu pengujian berakhir, bakteri - bakteri yang terdapat dalam digester belum selesai dalam tahap pendegradasian senyawa organik karena waktu tinggal yang hanya 14 hari.

\section{Kelayakan Limbah Tahu sebagai Biogas}

Kelayakan ini dilakukan dengan tujuan menganalisis biogas yang dihasilkan saat eksperimen serta simulasi pengaplikasian unit instalasi pengolahan limbah tahu pada industri tahu skala rumah tangga di Desa
Puspiptek, Tangerang Selatan dengan sistem anaerob dengan menganalisis aspek ekonomi dan lingkungannya.

\section{Pembuktian Biogas}

Uji kelayakan kandungan biogas secara ideal dilakukan dengan cara pengukuran komposisi metan dan karbon dioksida dengan alat spesifik tertentu. Namun, alat tersebut sudah lama tidak dioperasikan dan jika ingin menggunakan alat tersebut harus dilakukan pengkalibrasian terlebih dahulu. Maka dari itu, salah satu cara alternatif pembuktian biogas adalah dengan membakar gas yang telah ditampung dengan bara api. Namun, jumlah total volume biogas yang telah terproduksi selama pengujian tidak ditampung menyebabkan gas tidak dapat terbakar dengan sempurna.

\section{Simulasi Pemanfaatan Limbah Tahu Menjadi Biogas Pada Desa Puspiptek}

Pengaplikasian pengolahan limbah dengan metode digesti anaerobik pada industri tahu skala rumah tangga memerlukan reaktor yang bersifat kontinyu karena membutuhkan kapasitas yang lebih besar daripada tipe batch. Biaya investasi awal ini berdasarkan karakteristik unit biogas yang tercantum pada Prosiding Seminar Nasional Kimia tentang instalasi pengolahan air limbah biogas pada industri tahu, oleh Triyasa (2014), yaitu kapasitas produksi tahu $600 \mathrm{~kg} /$ hari, debit air limbah $6 \mathrm{~m}^{3} /$ detik, dan jumlah pengrajin 1 orang. Sistem pengolahan IPAL Anaerob, ukuran bak penampung 0,8 $\times 0,8 \times$ $1,2 \mathrm{~m}=0,768 \mathrm{~m}^{3}$, bak anaerob $30 \mathrm{~m}^{3}$, bak pelimpahan $2,4 \mathrm{~m}^{3}$. Waktu tinggal: bak penampung 3,6 jam, bak anaerob 6 hari, bak pelimpahan: 11,5 jam, jenis bak: fixed dome digester.

Tabel 5. Investasi Tetap

\begin{tabular}{cccccc}
\hline No & Jenis & $\begin{array}{c}\text { Jumla } \\
\mathrm{h}\end{array}$ & $\begin{array}{c}\text { Umu } \\
\mathrm{r} \\
\text { (th) }\end{array}$ & $\begin{array}{c}\text { Nilai Investasi } \\
(\mathrm{Rp})\end{array}$ & $\begin{array}{c}\text { Penyusutan } \\
(\mathrm{Rp})\end{array}$ \\
\hline 1 & *Unit Anaerob & 1 & 10 & 31.468 .165 & 3.146 .816 \\
2 & Bak Perendam & 1 & 10 & 200.000 & 20.000 \\
3 & Bak Pencucian & 1 & 10 & 200.000 & 20.000 \\
4 & Alat Penggiling & 1 & 10 & 1.500 .000 & 150.000 \\
5 & Tungku Pemanas & 2 & 10 & 650.000 & 65.000 \\
6 & Bak Penampung Tahu & 1 & 10 & 200.000 & 20.000 \\
7. & Meja Pencetakan Tahu & 1 & 10 & 200.000 & 20.000 \\
8. & Rak Penyimpanan & 3 & 10 & 300.000 & 30.000 \\
& Tahu Total & & & 34.718 .165 & 3.471 .816 \\
\hline
\end{tabular}


Tabel 6. Biaya Variabel

\begin{tabular}{ccccc}
\hline No. & Variabel & Jumlah & Harga $(\mathrm{Rp}) /$ unit & $\begin{array}{c}\text { Total } \\
(\mathrm{Rp})\end{array}$ \\
\hline 1 & Tenaga Kerja & 6 & 600.000 & 3.600 .000 \\
2 & Toren 520 L & 1 & 750.000 & 750.000 \\
3 & Listrik I-1/450 VA & 200 & 485 & 97.000 \\
& & & 4.447 .000 \\
\hline
\end{tabular}

\section{Analisis Kelayakan Aspek Ekonomi}

Umur ekonomis usaha diperkirakan 10 tahun dalam 1 tahun berproduksi selama 6 bulan dengan setiap bulannya selama 30 hari, sedangkan tingkat bunga yang berlaku diasumsikan $20 \%$ dan biaya produksinya adalah sebagai berikut:

Biaya produksi per bulan

$=30 \times \mathrm{Rp} 4.447 .000$

= Rp133.410.000,-

Biaya produksi per tahun

$=6 \times \operatorname{Rp} 133.410 .000$

$=$ Rp800.460.000.-

Kapasitas produksi $(\mathrm{kg})=600 \mathrm{~kg} / \mathrm{hr}$

$$
=109.500 \mathrm{~kg} / \mathrm{thn}
$$

Perhitungan dilakukan per tahun dengan menggunakan indikator - indikator kelayakan ekonomi yang sederhana yaitu :

Harga pokok penjualan (HPP)

Harga pokok penjualan adalah suatu metode untuk menentukan harga biogas per $\mathrm{kg}$, di mana hasil perhitungannya adalah sebagai berikut :

Total cost

= Penyusutan + Biaya Produksi

$=$ Rp3.471.816 + Rp800.460.000

$=$ Rp803.931.816,-

HPP

= Total cost (TC) per tahun dibagi dengan total produksi per tahun

$=R p$ 803.931.816/109.500kg

$=$ Rp7.342 per $\mathrm{kg}$

Dari hasil perhitungan maka harga pokok penjualan biogas adalah $\mathrm{Rp} 7.342$ per $\mathrm{kg}$, diasumsikan penjualan per $\mathrm{kg}$ adalah

Rp8.000.

Titik Impas (BEP)

BEP (break event point) terjadi jika total cost

(TC) sama dengan total revenue (TR), maka

hasil perhitungannya adalah :

$\mathrm{BEP}=\mathrm{Rp} 803.931 .816 / \mathrm{Rp} 7.342$

$$
=109.500 \mathrm{~kg} / \mathrm{thn}
$$

Keuntungan tahun ke - 1

= penjualan per tahun - biaya produksi per tahun

$=(\mathrm{Rp} 8.000 \times 109.500)-\mathrm{Rp} 803.931 .816$

$=\operatorname{Rp} 72.068 .184,-$

Pay Back Period (PBP)

Perhitungan PBP ini dilengkapi dengan rasio keuntungan dan biaya dengan nilai sekarang. PBP

$=$ Nilai investasi $/$ Keuntungan tahun 1
$=\mathrm{Rp} 34.718 .165 / \mathrm{Rp} 72.068 .184$

$=0,48$

Pay Back Period yang didapatkan adalah 0,48 , maka dalam jangka waktu 5,76 bulan usaha ini telah kembali modal.

\section{Jumlah Biogas yang Dihasilkan}

Untuk menghitung jumlah biogas yang dihasilkan, maka kapasitas limbah harus diperhitungkan, dengan menggunakan rumus berikut:

Kapasitas Limbah = Koefisien Limbah $\mathrm{x}$ Jumlah Kedelai

Di mana, koefisien limbah sebesar 9,46 L/kg untuk limbah tahu skala rumah tangga (Sadzali, 2010).

Kapasitas Limbah = 9,46 L/kg x $600 \mathrm{~kg} /$ hari

$$
\begin{aligned}
& =5676 \mathrm{~L} / \text { hari } \\
& =5,676 \mathrm{~m}^{3} / \text { hari }
\end{aligned}
$$

Pengolahan limbah tahu $90 \mathrm{~L}=0,08204 \mathrm{~m}^{3}$ biogas (Ridhuan, 2009). Maka, jumlah biogas yang dihasilkan dari kapasitas limbah $2838 \mathrm{~L}$ adalah:

Jumlah biogas $=5676 / 90 \mathrm{~L} \times 0,08204 \mathrm{~m}^{3}$

Jumlah biogas $=5,174 \mathrm{~m}^{3} /$ hari

\section{Perbandingan Biogas Dengan Bahan Bakar Lain}

Perbandingan dengan LPG (Bright 5,5 kg)

Nilai kalor biogas

$=4.785 \mathrm{kkal} / \mathrm{m}^{3}=4,785 \mathrm{kkal} / \mathrm{L}$ (Tabel 8)

Nilai kalor LPG

$=10.882 \mathrm{kkal} / \mathrm{m}^{3}=10,882 \mathrm{kkal} / \mathrm{L}($ Tabel 8)

Harga LPG

$=(\mathrm{Rp} 270.000,00 / 5,5 \mathrm{~kg}) /(500 \mathrm{~L} / \mathrm{kg})$

$=$ Rp98.182 per liter

Harga biogas

$=4,785 / 10,882 \mathrm{kkal} / \mathrm{L}$ x Rp98.182

Harga biogas terhadap LPG

= Rp43.172 per liter

Dari perbandingan harga biogas dengan gas LPG, didapat nilai harga biogas sebesar Rp43.172. Maka, dengan menggunakan biogas sebagai bahan bakar alternatif LPG, dapat menghemat pengeluaran sebesar Rp55.010.

Perbandingan dengan Minyak Tanah

Nilai kalor biogas

$=4.789 \mathrm{kkal} / \mathrm{m}^{3}=4,789 \mathrm{kkal} / \mathrm{L}$

Nilai kalor minyak tanah

$=10.478 \mathrm{kkal} / \mathrm{m}^{3}=10,478 \mathrm{kkal} / \mathrm{L}$

Harga minyak tanah $=$ Rp10.450 per liter 
Harga biogas

$=4,785 / 10,478 \mathrm{kkal} / \mathrm{L} \times \mathrm{Rp} 10.450,00$

Harga biogas terhadap miyak tanah

= Rp4.772 per liter

Dari perbandingan harga biogas dengan minyak tanah, didapat nilai harga biogas sebesar Rp4.772. Maka, dengan menggunakan biogas sebagai bahan bakar alternatif minyak tanah, dapat menghemat pengeluaran sebesar Rp5.678.

Perbandingan dengan Kayu Bakar

Nilai kalor biogas

$=4.789 \mathrm{kkal} / \mathrm{m}^{3}=4,789 \mathrm{kkal} / \mathrm{L}$

Nilai kalor untuk kayu bakar

$=4.266 \mathrm{kkal} / \mathrm{kg}=4,266 \mathrm{kkal} / \mathrm{L}$

Harga kayu bakar = Rp25.000 per pikul

Harga biogas

= 4,785/4,266 kkal/L x Rp25.000

Harga biogas terhadap kayu bakar

= Rp28.041 per liter

Dari perbandingan harga biogas dengan kayu bakar, didapat nilai harga biogas sebesar Rp28.041 per liter. Dari hasil perhitungan ini, dengan menggunakan biogas sebagai bahan bakar alternatif kayu bakar, pengeluaran yang dibutuhkan bertambah sebesar Rp3.041.

Tabel 8. Nilai Kalor Bahan Bakar

\begin{tabular}{|l|l|l|l|}
\hline Jenis & $\begin{array}{l}\text { Nilai } \\
\text { Kalor }\end{array}$ & Harga & Sumber \\
\hline Biogas & $\begin{array}{l}4785 \\
\mathrm{kkal} / \mathrm{m}^{3}\end{array}$ & - & - \\
\hline LPG & $\begin{array}{l}10882 \\
\mathrm{kkal} / \mathrm{m}^{3}\end{array}$ & $\mathrm{Rp} 270.000$ & $\begin{array}{l}\text { Pertamina, } \\
2018\end{array}$ \\
\hline $\begin{array}{l}\text { Minyak } \\
\text { Tanah }\end{array}$ & $\begin{array}{l}10478 \\
\mathrm{kkal} / \mathrm{m}^{3}\end{array}$ & $\mathrm{Rp} 10.450$ & $\begin{array}{l}\text { Pertamina, } \\
2018\end{array}$ \\
\hline $\begin{array}{l}\text { Kayu } \\
\text { Bakar }\end{array}$ & $\begin{array}{l}4266 \\
\mathrm{kkal} / \mathrm{kg}\end{array}$ & $\mathrm{Rp} 25.000$ & $\begin{array}{l}\text { Poskotanews, } \\
\text { 2018 }\end{array}$ \\
\hline
\end{tabular}

Maka, dari keseluruhan hasil perhitungan tersebut dapat disimpulkan bahwa biogas dapat dijadikan alternatif bahan bakar yang terjangkau dan ramah lingkungan dibandingkan dengan bahan bakar LPG dengan penghematan pengeluaran sebesar Rp55.010 dan minyak tanah dengan penghematan pengeluaran sebesar Rp5.678. Namun, harga biogas terhadap kayu bakar lebih mahal Rp3.041 tanpa memperhitungkan aspek kerugian terhadap lingkungan.

Analisis Kelayakan Aspek Lingkungan

Dengan adanya pemanfaatan limbah tahu menjadi biogas, maka bahan bakar fosil dapat tergantikan dengan bahan bakar alternatif yang ekonomis dan ramah lingkungan. Penggunaan biogas sebagai bahan bakar alternatif ini dapat menurunkan emisi gas metan dan karbon dioksida secara signifikan (Elizabeth \& Rusdiana, 2011). Biogas tidak saja dapat digunakan pada kegiatan rumah tangga, namun dapat juga digunakan untuk produksi tahu jika diolah dengan benar. Residu limbah yang dihasilkan dari pengolahan limbah menjadi biogas dapat digunakan sebagai pupuk organik yang kaya dengan unsur hara. Pupuk ini tidak lagi mengundang parasit dan biji gulma yang dapat tumbuh, sehingga tidak ada unsur yang berbahaya (Elizabeth \& Rusdiana, 2011). Oleh karena tidak ada limbah yang tersisa, maka disebut dengan istilah zero waste.

Selain itu, biogas dapat mengurangi pencemaran terhadap lingkungan, baik pada aspek air dengan mengurangi pembuangan limbah cair tahu ke badan air, aspek udara dengan mengurangi polusi berupa bau yang dihasilkan dari limbah tahu, maupun aspek tanah dengan mengurangi polusi limbah cair yang masuk ke tanah yang dapat merusak air tanah, serta diharapkan masalah aspek sosial antar masyarakat tidak terganggu dengan keberadaan limbah tahu yang pada umumnya menimbulkan bau yang sangat menyengat.

\section{Kesimpulan}

Jumlah volume biogas yang dihasilkan dari pemanfaatan limbah tahu skala rumah tangga dengan inokulum berupa kotoran sapi adalah sebesar 1,525 liter dengan waktu tinggal 14 hari. Keberhasilan proses fermantasi limbah organik dibuktikan dengan terjadinya penurunan kandungan COD sebesar 8,1\%, Total Solid sebesar 56,9\%, dan Volatile Solid sebesar 66,3\%. Pembuktian biogas hasil pengujian dilakukan dengan cara visualisasi, namun gas yang tertampung dalam volume pengukur tidak cukup untuk menghasilkan pembakaran sempurna.

Hasil analisis simulasi kelayakan biogas berdasarkan aspek ekonomi berupa HPP Rp7.342 per kg, BEP 109.500 kg/tahun, dan PBP 0,48 dengan pengolahan limbah tahu sebesar 5676 liter per hari, menghasilkan biogas sebanyak $5,174 \mathrm{~m}^{3}$ per hari. Hasil analisis kelayakan biogas berdasarkan aspek lingkungan adalah dengan pemanfaatan limbah tahu menjadi biogas dapat mengurangi pencemaran terhadap lingkungan, baik pada aspek air, udara, maupun tanah, serta masalah aspek sosial antar masyarakat.

Ucapan Terima Kasih: Terima kasih kepada Bapak Dr. Badrus Zaman, S.T., M.T. selaku Ketua Departemen Teknik Lingkungan Universitas Diponegoro, Bapak Dr. -Ing. M. Abdul Kholiq, M.Sc. selaku pembimbing kerja praktik di Badan Pengkajian dan Penerapan Teknologi, serta kepada segenap pihak lain yang turut membantu pelaksanaan dan penyusunan laporan kerja praktik. 


\section{Daftar Pustaka}

Clemens, J., Kohne, S., Weser-ems, S. N. S., \& Schreier, W. (2012). Leakage control of biogas plants. ORBIT, 1-8.

Deublein, D. and S.Angelika. 2008. Biogas from Waste and Renewable Resource. Weinheim: Wiley - VCH Verlag GmbH \& Co. KGaA.

Elizabeth, R., \& Rusdiana, S. (2011). Efektivitas Pemanfaatan Biogas sebagai Sumber Bahan Bakar dalam Mengatasi Biaya Ekonomi Rumah Tangga di Perdesaan, 220-234.

Hutagulung, H. (2017). Pengaruh Waktu Tinggal Dan Komposisi Bahan Baku Pada Proses Fermentasi Terhadap Produktivitas Biogas Limbah Cair Industri Tahu Di Desa Sindang Sari. UNILA, Departemen Teknik Mesin, Skripsi. Lampung: Universitas Lampung.

Maragkaki, A. E., Fountoulakis, M., Kyriakou, A., Lasaridi, K., \& Manios, T. (2018). Boosting Biogas Production from Sewage Sludge by Adding Small Amount of Agro-Industrial ByProducts and Food Waste Residues. Waste Management, 71, 605-611. https://doi.org/10.1016/i.wasman.2017 .04 .024

Hutagulung, H. (2017). Pengaruh Waktu Tinggal dan Komposisi Bahan Baku Pada Proses Fermentasi terhadap Produktivitas Biogas Limbah Cair Industri Tahu di Desa Sindang Sari. Lampung University.

Indriyati. (2003). Proses Pembenihan dan Aklimatisasi pada Reaktor Tipe Fixed Bed. P3L - BPPT, 2, 54-60.

Marsudi. (2012). Produksi Biogas dari Limbah Rumah Tangga sebagai Upaya Mengatasi Krisis Energi dan Pencemaran Lingkungan.
Subekti, S. (2011). Pengolahan Limbah Cair Tahu menjadi Biogas sebagai Bahan Bakar Slternatif. In Sains dan Teknologi (pp. 61-66).

Triwikantoro, P. (2012). Pengaruh Tetes Tebu dan Limbah Cair Tahu pada Produksi Biogas. Fisika Dan Aplikasinya, 8(2), 4-7.

Peraturan Menteri Lingkungan Hidup Republik Indonesia Nomor 5 Tahun 2014.

Pertamina. (2018). Diakses tanggal 16 April 2018, dari web site: https://www.pertamina.com/id/news$\mathrm{room} /$ news-release/harga-perdanabright-gas-5-5-kg-turun-pertaminajuga-tebar-promo-khusus-trade-in.

Pertamina. (2018). Diakses tanggal 16 April 2018, dari web site: https://www.pertamina.com/id/newsroom/announcement/daftar-hargabbk-tmt-24-maret2018.

Poskota News. (2018). Diakses tanggal 16 April 2018, dari web site: http://poskotanews.com/2018/01/09/m adih-kakek-88-tahun-ini-masih-kuatjual-kayu-bakarl.

Ridhuan, K. (2009). Pengolahan Limbah Cair Tahu Sebagai Energi Alternatif Biogas yang ramah lingkungan, (115), 1-9.

Sadzali, I. (2010). Potensi limbah tahu sebagai biogas, 1, 62-69.

Sulistyono. 2016. Pemanasan Global (Global Warming) dan Hubungannya dengan Penggunaan Bahan Bakar Fosil. Jurnal Forum Teknologi, 2, 2.

Triyasa, A. (2014). Analisis Kelayakan Lingkungan dan Ekonomi Instalasi Pengolahan Air Limbah Biogas pada Industri Tahu. Seminar Nasional Kimia (pp. 80-89). Bandung: ISBN 978-602-0951-00-3. 